Katsuya Mikawa MD, Kahoru Nishina MD, Nobuhiro Maekawa MD, Migiwa Asano MD, Hidefumi Obara MD

\title{
Lansoprazole reduces preoperative gastric fluid acidity and volume in children
}

The purpose of this study was to explore the efficacy of lansoprazole, a proton pump inhibitor, in reducing the acidity and volume of gastric aspirate in children immediately following the induction of anaesthesia. One hundred healthy in-patients aged 3-11 yr undergoing elective surgery were randomly allocated to four groups ( $n=25$ each): lansoprazole-lansoprazole, placebo-placebo, placebo-lansoprazole, and lansoprazoleplacebo. For each treatment regimen, the first medication was administered at $9.00 \mathrm{pm}$ on the night before surgery and the second at 5:30 am on the morning of the day of surgery (three hours preoperatively). The dose of lansoprazole was $30 \mathrm{mg}$ (approximately $1.4 \mathrm{mg} \cdot \mathrm{kg}^{-1}$ mean). Children were offered 10 $\mathrm{ml} \cdot \mathrm{kg}^{-1}$ apple juice three hours before induction of anaesthesia. After induction of anaesthesia and tracheal intubation, gastric fluid was aspirated through a large-bore, multiorifice orogastric tube and analyzed for $\mathrm{pH}$ and total fluid volume. Lansoprazole increased gastric fluid $\mathrm{pH}$ and decreased gastric fluid volume regardless of whether it was administered before or after placebo. Two consecutive doses of lansoprazole was the most effective means of increasing the $\mathrm{pH}$ and reducing the volume of gastric aspirate; in this group, there were no subjects with gastric aspirate volume $>0.4 \mathrm{ml} \cdot \mathrm{kg}^{-1}$ and $\mathrm{pH}$ $<2.5$. Oral lansoprazole, at least $30 \mathrm{mg}$, given on the night before surgery or on the morning of surgery will improve the gastric environment at the time of induction of paediatric anaesthesia. The most effective regimen was two doses (at bedtime and on the morning) of lansoprazole.

\section{Key words}

ANAESTHESIA: paediatric;

COMPLICATIONS: aspiration;

GASTROINTESTINAL TRACT: gastric fluid volume, gastric $\mathrm{pH}$;

PREMEDICATION: lansoprazole.

From the Department of Anaesthesiology, Kobe University School of Medicine, Kusunoki-cho 7, Chuo-ku, Kobe 650, Japan.

Address correspondence to: Dr. K. Mikawa, Department of Anaesthesiology, Kobe University School of Medicine,

Kusunoki-cho 7, Chuo-ku, Kobe 650, Japan.

Accepted for publication 18th February, 1995.
Cette étude a pour objectif l'évaluation de l'efficacité du lansoprazole, un inhibiteur de la pompe à proton, sur la réduction de l'acidité et du volume du contenu gastriques chez l'enfant mesurés immédiatement après linduction de l'anesthésie. Cent sujets bien portants âgés de 3 à 11 ans hospitalisés pour une chirurgie non urgente sont répartis au hasard en quatre groupes ( $n=25$ par groupe) de la façon suivante: lansaprazole-lansaprazole, placebo-placebo, placebo-lansaprazole, et lansaprazole-placebo. Dans tous les cas, la première médication est administrée à 21.00 la veille de la chirurgie et la deuxième à 5:30 le matin de la chirurgie (trois heures avant lintervention). La dose de lansaprazole est de $30 \mathrm{mg}$ (environ $1,4 \mathrm{mg} \cdot \mathrm{kg}^{-1}$ en moyenne). On offre aux enfant $10 \mathrm{ml} \cdot \mathrm{kg}^{-1}$ de jus de pomme trois heures avant linduction de l'anesthésie. Après linduction et l'intubation de la trachée, le liquide gastrique est aspiré avec une sonde gastrique de gros calibre à plusieurs orifices et on analyse son $\mathrm{pH}$ et son volume. La lansaprazole augmente le $p H$ et diminue le volume du contenu gastrique quil soit administré avant ou après le placebo. Le moyen le plus efficace pour augmenter le $\mathrm{pH}$ et diminuer le volume est d'administrer deux doses de lansaprazole successives: dans ce groupe, le volume du contenu gastrique est toujours inférieur à $0,4 \mathrm{ml} \cdot \mathrm{kg}^{-1}$ et le pH supérieur à 2,5. Le lansaprazole, à la dose de 30 mg, administré par la bouche la veille ou le matin de la chirurgie améliore les paramètres gastrique au moment de linduction de l'anesthésie. La méthode la plus sûre est constituée par l'administration de dewx doses de lansaprazole, au coucher et le matin.

Paediatric general anaesthesia is associated with a risk of pulmonary aspiration of gastric contents ${ }^{\prime}$ and the incidence of this complication is higher than in adults. ${ }^{2,3}$ Children who come to the operating theatre have been shown to have a gastric fluid volume $>0.4 \mathrm{ml} \cdot \mathrm{kg}^{-1}$ and $\mathrm{pH}<2.5$ regardless of the fasting interval ${ }^{4-8}$ Patients who fulfill these criteria are believed to be at increased risk of developing aspiration pneumonitis. ${ }^{9,10}$ Several pharmacological interventions have proved successful in reducing the risk of lung damage by decreasing gastric acid secretion in paediatric surgery. ${ }^{1,7,8,11-15}$ Histamine $_{2}$ $\left(\mathrm{H}_{2}\right)$-receptor antagonists, including cimetidine, ranitidine, 
and famotidine, have been used in the preoperative period to modify gastric fluid environment prior to the induction of paediatric anaesthesia. ${ }^{7,8,11-15}$ Omeprazole which inhibits $\mathrm{H}^{+} / \mathrm{K}^{+}$-ATPase (proton pump) in parietal cells and thereby decreases gastric fluid, when given as a premedication, has recently been shown to reduce preoperative gastric fluid acidity and volume in children. ${ }^{16}$

Lansoprazole is a new potent proton pump inhibitor. ${ }^{17}$ The drug is transformed into its active forms within the acid-forming space. ${ }^{18}$ The active inhibitors react with the SH groups of the proton pump, resulting in the inhibition of acid formation. Lansoprazole inhibits acid secretion provoked by histamine, carbachol, or dibutyryl cyclic AMP although $\mathrm{H}_{2}$ receptor antagonists selectively suppress histamine-stimulated acid formation. ${ }^{18}$ This observation is explained by the difference in the mechanisms between lansoprazole and $\mathrm{H}_{2}$ receptor antagonists. There are considered to be mainly three routes (i.e., vagal, histaminergic, and gastrinergic) through which the proton pump in parietal cells, the final common pathway of gastric acid secretion, is activated. ${ }^{19}$ Since lansoprazole inhibits activation of this final step coupled with the various stimuli, the drug is more potent in reducing gastric acidity than $\mathrm{H}_{2}$ receptor antagonists which inhibit stimulation through only the histaminergic pathway. ${ }^{18}$ Lansoprazole produces rapid and prolonged inhibition of this enzyme ${ }^{20}$ and has been orally used in the treatment of peptic ulcer, reflux oesophagitis, and Zollinger-Ellison syndrome with few side effects. ${ }^{20-23}$ We undertook a controlled, randomized, and prospective study to evaluate the efficacy of preoperative oral lansoprazole in controlling gastric fluid $\mathrm{pH}$ and volume in children.

\section{Methods}

To make the assessment of the efficacy of lansoprazole, we used three different regimens of the drug: $30 \mathrm{mg}$ at bedtime before surgery, $30 \mathrm{mg}$ on the morning of the day of surgery, and combination of the two doses ( 60 $\mathrm{mg}$ in total). For this study, institutional approval was obtained from the clinical investigation review board of Kobe University Hospital. For all subjects, informed consent was obtained from the parents of all children on the day before surgery. We studied 100 otherwise healthy children (ASA physical status 1), aged 3-11 yr, undergoing elective surgery (ophthalmological, otological, orthopaedic, or urological surgery) as inpatients. Subjects with gastrointestinal disease, obese patients $>20 \%$ heavier than their ideal body weight, and those taking medication known to affect gastric fluid composition or gastric emptying were excluded. The children were randomly (using an envelope method) assigned to one of four treatments as follows ( $n=25$ for each group): lansoprazole-lansoprazole, placebo-placebo (as a control group), placebo-lansoprazole, and lansoprazole-placebo. Subjects in the lansoprazole-lansoprazole group received two doses of lansoprazole $\left(30 \mathrm{mg}\right.$ per dose, Takepron ${ }^{\circledR}$, Takeda, Japan), those in the placebo-placebo group, two doses of placebo, those in the placebo-lansoprazole and lansoprazole-placebo group, one dose each of the two preparations by mouth. For each treatment regimen, the first medication was administered at $9: 00 \mathrm{pm}$ on the night before surgery and the second at 5:30 am on the morning of the day of surgery.

Milk and solids were administered until 9:00 pm on the day before surgery. The patients were instructed to ingest a large volume of apple juice $\left(10 \mathrm{ml} \cdot \mathrm{kg}^{-1}\right)$ three hours before induction of anaesthesia (at 5:30 am on the day of surgery).

Induction of anaesthesia in all cases was started at 8:30 am. After preoxygenation with $100 \%$ oxygen by mask, anaesthesia was induced with nitrous oxide $\left(\mathrm{N}_{2} \mathrm{O}\right)$ $4 \mathrm{~L} \cdot \min ^{-1}$, oxygen $2 \mathrm{~L} \cdot \mathrm{min}^{-1}$, and halothane in gradually increasing concentrations up to $1.5 \%$ inspired. Infusion (lactated Ringer's solution) was started immediately after we confirmed loss of consciousness of children. Atropine $0.01 \mathrm{mg} \cdot \mathrm{kg}^{-1} i v$ was then administered through a three-way stopcock to prevent bradycardia and hypotension. After injection of atropine, the inspired halothane concentration was increased to $2.5 \%$. The lungs were ventilated taking care to avoid inflation of the stomach. Tracheal intubation was facilitated by vecuronium bromide $0.1 \mathrm{mg} \cdot \mathrm{kg}^{-1} \dot{w}$. All inductions were uneventful and no patients had coughing, laryngospasm, or vomiting during induction.

Following tracheal intubation, a 16-Fr Argyle Salem Sump ${ }^{\circledR}$ catheter was inserted into the stomach. Placement of the orogastric tube within the stomach was verified by auscultation over the epigastrium during introduction of $5-10 \mathrm{ml}$ air. Gastric fluid samples were obtained by gentle aspiration with a $50-\mathrm{ml}$ syringe by an investigator who was unaware which pre-anaesthetic medication the patient had received. Aspirations were attempted with the child held in the supine, reverse Trendelenburg, and both lateral positions to maximize gastric emptying. Pressure was applied over the epigastrium with the patient held in the supine and then in the left and right lateral decubitus positions to ensure maximum emptying of gastric fluid. Gastric contents were visually inspected for particles and the volume of gastric contents was measured with the syringe. The $\mathrm{pH}$ of the gastric fluid was immediately determined using a $\mathrm{pH}$ meter (Horiba F-8L, Japan) which was calibrated using standard buffers at $\mathrm{pH}$ values of 2,4 , and 7 . The $\mathrm{pH}$ meter has $0.01 \mathrm{pH}$ units precision over the entire $\mathrm{pH}$ range.

The age, weight, volume of apple juice ingested, and gastric fluid $\mathrm{pH}$ and volume were recorded for each patient. 
TABLE I Demographic data of patients. Values are expressed as mean \pm SD

\begin{tabular}{lllll}
\hline Groups & $\begin{array}{l}\text { Placebo- } \\
\text { placebo }\end{array}$ & $\begin{array}{l}\text { Lansoprazole- } \\
\text { placebo }\end{array}$ & $\begin{array}{l}\text { Placebo- } \\
\text { lansoprazole }\end{array}$ & $\begin{array}{l}\text { Lansoprazole- } \\
\text { lansoprazole }\end{array}$ \\
\hline$n$ & 25 & 25 & 25 & 25 \\
Age $(\mathrm{yr})$ & $6.5 \pm 1.4$ & $6.6 \pm 1.5$ & $7.1 \pm 1.7$ & $6.9 \pm 1.6$ \\
$\begin{array}{l}\text { Weight }(\mathrm{kg}) \\
\begin{array}{l}\text { Volume of apple juice ingested } \\
\left(\mathrm{m} \cdot \mathrm{kg}^{-1}\right)\end{array}\end{array}$ & $21 \pm 3.8$ & $22 \pm 3.9$ & $24 \pm 4.1$ & $23 \pm 4.0$ \\
\hline
\end{tabular}

At any variables: $P>0.05$.

TABLE II Gastric Fluid Analysis

\begin{tabular}{|c|c|c|c|c|}
\hline & $\begin{array}{l}\text { Placebo- } \\
\text { placebo }\end{array}$ & $\begin{array}{l}\text { Lansoprazole- } \\
\text { placebo }\end{array}$ & $\begin{array}{l}\text { Placebo- } \\
\text { lansoprazole }\end{array}$ & $\begin{array}{l}\text { Lansoprazole- } \\
\text { lansoprazole }\end{array}$ \\
\hline \multicolumn{5}{|l|}{ Gastric fluid volume $\left(\mathrm{ml} \cdot \mathrm{kg}^{-1}\right)$} \\
\hline $\begin{array}{l}- \text { Mean } \pm \text { SD } \\
\text { - (range) }\end{array}$ & $\begin{array}{l}0.62 \pm 0.54 \\
(0-2.5)\end{array}$ & $\begin{array}{l}0.29 \pm 0.24^{*} \\
(0-0.91)\end{array}$ & $\begin{array}{l}0.24 \pm 0.16^{*} \\
(0-0.56)\end{array}$ & $\begin{array}{l}0.20 \pm 0.12^{*} \\
(0-0.48)\end{array}$ \\
\hline $\begin{array}{l}\text { Gastric fluid volume }>0.4 \mathrm{ml} \cdot \mathrm{kg}^{-1} \\
\text { Gastric fluid } \mathrm{pH}\end{array}$ & $13 / 25(52 \%)$ & $7 / 25(28 \%)$ & $3 / 25(12 \%)^{*} \dagger$ & $2 / 25(8 \%)^{*} \dagger$ \\
\hline $\begin{array}{l}- \text { mean } \pm S D \\
- \text { (range) }\end{array}$ & $\begin{array}{l}1.97 \pm 0.56 \\
(0.7-3.7)\end{array}$ & $\begin{array}{l}2.79 \pm 1.24^{*} \\
(1.0-6.9)\end{array}$ & $\begin{array}{l}3.43 \pm 1.54^{*} \\
(1.2-7.2)\end{array}$ & $\begin{array}{l}5.07 \pm 1.49 * \ddagger \ddagger \\
(2.2-7.5)\end{array}$ \\
\hline Gastric fluid $\mathrm{pH}<2.5$ & $19 / 21(90 \%)$ & $8 / 20(40 \%)^{*}$ & $6 / 20(30 \%)^{*}$ & $1 / 19(5 \%)^{*} \ddagger \ddagger$ \\
\hline $\begin{array}{l}\text { Gastric fluid volume }>0.4 \mathrm{ml} \cdot \mathrm{kg}^{-1} \\
\text { and gastric fluid } \mathrm{pH}<2.5\end{array}$ & $11 / 25(44 \%)$ & $4 / 25(16 \%)^{*}$ & $2 / 25(8 \%)^{*}$ & $0 / 25(0 \%)^{*+}+$ \\
\hline
\end{tabular}

$* P<0.05$ vs placebo-placebo (control group).

$\dagger P<0.05$ vs lansoprazole-placebo group.

$\ddagger P<0.05$ vs placebo-lansoprazole group.

Comparisons of data between the groups were made using one-way analysis of variance and Bonferroni correction for multiple comparison of parametric data, while Kruskal-Wallis rank test was used for non-parametric data. The differences between the groups' risk factors for pulmonary acid-aspiration syndrome were tested for statistical significance by chi-square test. $P<0.05$ was deemed statistically significant.

\section{Results}

There were no differences among the four groups of patients with regard to age, weight, or volume of fluids ingested (Table I).

Although gastric fluid was obtained from all children enrolled in the current study, the volume was sufficient for $\mathrm{pH}$ determination only in 80 of the 100 samples. In the remainder, a very small quantity of gastric fluid remained in the gastric tube. It could not be aspirated into the syringe. These small quantities of gastric fluid were arbitrarily regarded as a residual volume of $0 \mathrm{ml}$. Compared with the placebo-placebo (control) group, gastric fluid volume was less in all of the other three regimen groups (Table II). Lansoprazole, regardless of the time of administration, increased gastric fluid $\mathrm{pH}$. Two doses of lansoprazole $(60 \mathrm{mg})$ were the most effective in de- creasing gastric acidity. Lansoprazole reduced the number of children with a gastric fluid $\mathrm{pH}<2.5$ and gastric fluid volume $>0.4 \mathrm{ml} \cdot \mathrm{kg}^{-1}$ compared with the control group (placebo-placebo: $44 \%$, lansoprazole-placebo: $16 \%$, placebo-lansoprazole: $8 \%$ and lansoprazole-lansoprazole: 0\%).

Children did not have particulate matter in their gastric aspirates. Adverse reactions (eruption, headache, diarrhoea, constipation, and fever) related to lansoprazole were not noted before surgery.

\section{Discussion}

In the present study, a single dose of $30 \mathrm{mg}$ lansoprazole given either the night before surgery or on the morning of the day of surgery successfully reduced the acidity and volume of gastric aspirate in children. Administration of lansoprazole in two successive doses $(60 \mathrm{mg}$ in total) seemed to be more effective in modulating gastric fluid properties than a single dose of the drug. This may be due to an additive effect of two doses of lansoprazole.

Lansoprazole has an accepted place in clinical practice for the treatment of severe reflux oesophagitis, refractory peptic ulcer, and Zollinger-Ellison syndrome in adults. ${ }^{20-23}$ For these purposes, oral administration of lansoprazole at doses of $30-120 \mathrm{mg} \cdot$ day $^{-1}$ for several 
months is advocated. ${ }^{20-24}$ Lansoprazole at doses of 7.5-60 $\mathrm{mg} \cdot$ day $^{-1}$ given for 14-34 days has been proved effective in the treatment of duodenal ulcer in six children (13-17 yr). ${ }^{25}$ No severe adverse effects were observed in these reports. Lansoprazole is a weak base $\left(\mathrm{pK}_{\mathrm{a}}=4-4.5\right)^{25}$ so that it is unstable in acid environments. The drug is therefore formulated as a capsule containing enteric coated granules to permit rapid absorption from the small intestine. This characteristic of lansoprazole precluded us from pulverizing the granules. Furthermore, in the present study, doses of $1.3-2.6 \mathrm{mg} \cdot \mathrm{kg}^{-1}$ were used because $30 \mathrm{mg}$ capsules are the only dosage form available in Japan. Thus, we studied the upper dose range of this medication. However, $15 \mathrm{mg}$ capsules are available in some countries, where the effect of the drug at its optimal dose may be evaluated.

The time of dosing for lansoprazole, three hours before anaesthesia in the placebo-lansoprazole and lansoprazole-lansoprazole groups, was chosen because $T_{\max }$ of lansoprazole ranges between $1.5-2 \mathrm{hr}$ after oral $30 \mathrm{mg}$ administration ${ }^{20-25}$ and the onset of gastric anti-secretory effect of lansoprazole occurs within one hour after single oral lansoprazole $30 \mathrm{mg} .{ }^{26}$ Furthermore, lansoprazole has a prolonged effect $(>12 \mathrm{hr})^{27}$ because it is concentrated selectively in the acidic environment of the gastric parietal cell, where it remains at high levels for a long period of time. ${ }^{28}$ These pharmacological characteristics (rapid onset and long duration) may account for our observation that oral lansoprazole, even when given in a single dose at bedtime before surgery or on the morning of surgery, effectively decreased gastric acidity and volume. This rapid onset of action of lansoprazole encourages us to use the drug as a premedicant for paediatric out-patients. Further studies are required to evaluate the efficacy of lansoprazole in children undergoing ambulatory surgery.

As the incidence of aspiration has recently been reported to be as low as approximately $1: 10,000,29-31$ it is extremely unlikely that aspiration will occur in children who are not predisposed to regurgitation. Thus, prophylaxis of aspiration pneumonitis with lansoprazole in otherwise healthy children may have the minimal indications or use of this drug in children. However, its use might be considered in cases where airway difficulties are anticipated.' Children with reflux oesophagitis may constitute another group of patients who may benefit from the drug. In the present study, we used ASA physical status 1 children. This population was chosen to ensure a safe approach to the initial evaluation of lansoprazole's effects.

$\mathrm{H}_{2}$-antagonists (e.g., cimetidine, famotidine, and ranitidine) have been extensively studied as candidates for acid aspiration prophylaxis in otherwise healthy children presenting for routine surgery..$^{7,811-15}$ Since the reduction in gastric fluid volume is not a consistent finding in these studies, ${ }^{11-15}$ the ability of lansoprazole to decrease gastric volume may be an advantage. A rebound increase in gastric secretion following discontinuation of medication seems to occur less frequently with proton pump inhibitors than with cimetidine. ${ }^{32}$ Lansoprazole has little haemodynamic effect. ${ }^{33}$ The drug shows marked antibacterial activities against Helicobacter pylori, which is an important human pathogen causing type B gastritis and probably predisposes considerably to duodenal ulcer recurrence. ${ }^{34}$ This activity is similar to that of bismuth subcitrate and four times more potent than that of omeprazole. These characteristics may also be advantages of the drug.

Lansoprazole does not seem to interfere with drug metabolism by binding cytochrome $\mathrm{P}-450 .{ }^{35}$ Unlike cimetidine, no or little interactions with diazepam, ${ }^{36}$ antipyrine, ${ }^{37}$ warfarin ${ }^{38}$ or theophylline, ${ }^{39}$ all of which may be used in perioperative periods, have been observed in man. Lansoprazole has been shown to enhance secretion of bicarbonate, which is thought to be one of mucosal protective factors in the pathogenesis of peptic ulcer, from the duodenum compared with famotidine or omeprazole. ${ }^{40}$ These characteristics may give the drug an additional advantage.

In conclusion, we have shown that $30 \mathrm{mg}$ of oral lansoprazole, at bedtime before surgery or on the morning of surgery, increased preoperative gastric fluid $\mathrm{pH}$ and decreased gastric volume in children. The two doses (in a single $30 \mathrm{mg}$ dose at bedtime before surgery and an additional $30 \mathrm{mg}$ dose on the morning of the day of surgery), of lansoprazole was the most effective of the regimens studied in controlling gastric fluid environment. In children who are at risk of aspirating gastric contents, the reduction in volume of gastric fluid and the improvement of gastric $\mathrm{pH}$ by the drug can reasonably be anticipated to provide protection against the occurrence of pneumonitis, should regurgitation and aspiration of gastric contents occur.

\section{References}

1 Weaver $M K$. Perioperative pulmonary aspiration in children: a review. Paediatric Anaesthesia 1993; 3: 333-8.

2 Edwards G, Morton HJV, Pask EA, Wylie WD Deaths associated with anaesthesia. A report on 1000 cases. Anaesthesia 1956; 11: 194-200.

3 Utting JE, Gray TC, Shelley FC. Human misadventure in anaesthesia. Can Anaesth Soc J 1979; 26: 472-8.

4 Salem MR, Wong AY, Mani M, Bennett EJ, Toyama T. Premedicant drugs and gastric juice $\mathrm{pH}$ and volume in pediatric patients. Anesthesiology 1976; 44: 216-9.

5 Crawford M, Lerman J, Christensen S, Farrow-Gillespie A. 
Effects of duration of fasting on gastric fluid $\mathrm{pH}$ and volume in healthy children. Anesth Analg 1990; 71: 400-3.

6 Splinter WM, Stewart JA, Muir JG. Large volumes of apple juice preoperatively do not affect gastric $\mathrm{pH}$ and volume in children. Can J Anaesth 1990; 37: 36-9.

7 Goudsouzian N, Coté CJ, Liu LMP, Dedrick DF. The dose-response effects of oral cimetidine on gastric $\mathrm{pH}$ and volume in children. Anesthesiology 1981; 55: 533-6.

8 Goudsouzian N, Young ET. The efficacy of ranitidine in children. Acta Anaesthesiol Scand 1987; 31: 387-90.

9 Roberts RB, Shirley $M A$. Reducing the risk of acid aspiration during cesarean section. Anesth Analg 1974; 53 : 859-68.

10 James CF, Modell JH, Gibbs CP, Kuck EJ, Ruiz BC. Pulmonary aspiration - effects of volume and $\mathrm{pH}$ in the rat. Anesth Analg 1984; 63: 665-8.

11 Jahr JS, Burckart G, Smith SS, Shapiro J, Cook DR. Effects of famotidine on gastric $\mathrm{pH}$ and residual volume in pediatric surgery. Acta Anaesthesiol. Scand 1991; 35: 457-60.

12 Tryba $M$, Yildiz $F$, Kühn K, Dziuba M, Zenz M. Rectal and oral cimetidine for prophylaxis of aspiration pneumonitis in paediatric anaesthesia. Acta Anaesthesiol Scand 1983; 27: 328-30.

13 Christensen S, Farrow-Gillespie A, Lerman J. Effects of ranitidine and metoclopramide on gastric fluid $\mathrm{pH}$ and volume in children. Br J Anaesth 1990; 65: 456-60.

14 Guay J, Santerre L, Gaudreault P, Goulet B, Dupuis C. Effects of oral cimetidine and ranitidine on gastric $\mathrm{pH}$ and residual volume in children. Anesthesiology 1989; 71: 547-9.

15 Kemmotsu O, Mizushima M, Morimoto Y, et al. Effect of preanesthetic intramuscular ranitidine on gastric acidity and volume in children. J Clin Anesth 1991; 3: 451-5.

16 Nishina K, Mikawa K, Maekawa N, Tamada M, Obara $H$.Omeprazole reduces preoperative gastric fluid acidity and volume in children. Can J Anaesth 1994; 41: 925-9.

17 Satoh, H, Inatomi N, Nagaya H, et al. Antisecretory and antiulcer activities of a novel proton pump inhibitor AG1749 in dogs and rats. J Pharmacol Exp Ther 1989; 248: 806-15.

18 Nagaya $H$, Satoh $H$, Maki $Y$. Possible mechanism for the inhibition of acid formation by the proton pump inhibitor AG-1749 in isolated canine parietal cells. J Pharmacol Exp Ther 1990; 252: 1289-95.

19 Azumi Y, Saigenji K. The mechanism of action of proton pump inhibitor (Japanese). Review of Medicine and Pharmacology 1991; 9: 17-23.

20 Barradell LB, Faulds $D$, McTavish $D$. Lansoprazole. A review of its pharmacodynamic and pharmacokinetic properties and its therapeutic efficacy in acid-related disorders. Drugs 1992; 44: 225-50.

21 Mignon $M$, Vallot $T$. Acute treatment of duodenal ulcer: experience with lansoprazole. Aliment Pharmacol Ther 1993; 7: 37-40.

22 Sekiguchi T, Matsuzaki T, Horikashi T, et al. Clinical effects of lansoprazole in the treatment of reflux esophagitis (Japanese). Therapeutic Research 1991; 12: 191-212.

23 Kohrogi $N$, lida $M$, Fujishima $M$, et al. Zollinger-Ellison syndrome successfully treated with new proton pump inhibotor, lansoprazole: report of two cases (Japanese). Therapeutic Research 1991; 12: 917-28.

24 Ogoshi K, Kato T, Saito M, Niwa M, Watanabe H, Iwabuchi $M$. Clinical study of AG-1749 (lansoprazole): effects on serum gastrin levels and gastric mucosal ECL cell density (Japanese). Japanese Pharmacology and Therapeutics 1991; 19: 933-46.

25 Takeda Chemical Industries. Data on file: Takepron ${ }^{(19 .}$ Takeda Chemical Industries, Osaka, Japan.

26 Kihira K, Yoshida Y, Kasano T, et al. Effect of a proton pump inhibitor AG-1749 (lansoprazole) on intragastric pH: 24-hour intragastric pH monitoring (Japanese). Japanese Journal of Gastroenterology 1991; 88: 672-80.

27 Hongo M, Ohara S, Hirasawa Y, Abe S, Asaki S, Toyota T. Effects of lansoprazole on intragastric $\mathrm{pH}$. Comparison between morning and evening dosing. Digest Dis Sci 1992; 37: 882-90.

28 Sekiguchi $M$, Nagaya $H$, Satoh $H$, Shino $A$. Localization of a novel proton pump inhibitor, lansoprazole, in the gastric mucosa of the rat: a radioautographic study. Acta Histochemica Cytochemica 1992; 25: 405-10.

29 Olsson GL, Hallen B, Hambraeus-Jonzon K. Aspiration during anaesthesia: a computer-aided study of 185,358 anaesthetics. Acta Anaesthesiol Scand 1986; 30: 84-92.

30 Tiret L, Nivoche Y, Hatton F, Demonts JM, Vourch $G$. Complications related to anaesthesia in infants and children. Br J Anaesth 1988; 61: 263-9.

31 Tiret L, Demonts JM, Hatton F, Vourch $C$. Complications associated with anaesthesia - a prospective survey in France. Can Anaesth Soc J 1986; 33: 336-44.

32 Yashinari $M$, Minamida $Y$. New drug information from DI (Japanese). Review of Medicine and Pharmacology 1991; 9: 165-76.

33 Tateno $M$, Nakamura $N$. Phase I study of lansoprazole (AG-1749) antiulcer agent - capsule form (Japanese). Journal of Clinical Therapeutics and Medicine 1991; 7: 51-62.

34 Iwahi $T$, Satoh $H$, Nakao $M$, et al. Lansoprazole, a novel benzimidazole proton pump inhibitor, and its related compounds have selective activity against Helicobacter pylori. Antimicrob Agents Chemother 1991; 35: 490-6.

35 Miwa K, Mitani $M$, Tsukamoto $T$, et al. Metabolic fate of AG-1749, a new proton pump inhibitor, in rats, mice, and dogs (Japanese). Japanese Pharmacology and Therapeutics 1990; 18: 3413-35.

36 Lefebvre RA, Fouvat B, Karolac-Tamisier S, Moerman E, Ganse $E V$. Influence of lansoprazole treatment on diaze- 
pam plasma concentrations. Clin Pharmacol Ther 1992: 52;

458-63.

37 Cavanaugh JH, Park YK, Awni NM, Mukherjee DX, Karol MD, Granneman GR. Effect of lansoprazole on antipyrine and ICG pharmacokinetics. Gastroenterology 1991; 100: A40.

38 Cavanaugh JH, Winters EP, Cohen A, Locke CS, Braeckman $R$. Lack of effect of lansoprazole on steady state warfarin metabolism. Gastroenterology 1991; 100: A40.

39 Granneman G, Winters EP, Locke CS, Leese PT, Karol $M D$, Cavanaugh JH. Lack of effect of concomitant lansoprazole on steady-state theophylline pharmacokinetics. Gastroenterology 1991; 100: A75.

40 Inada I, Inatomi $N$, Satoh $H$. Effect of lansoprazole (AG1749) on duodenal bicarbonate secretion in anesthetized rats (Japanese). Japanese Pharmacology and Therapeutics 1992; 20: 4345-50. 